\title{
NEW ESTIMATION OF THE REMAINDER IN TAYLOR'S FORMULA USING GRÜSS' TYPE INEQUALITIES AND APPLICATIONS
}

\author{
SEVER SILVESTRU DRAGOMIR
}

Abstract. Some perturbed Taylor's expansions via Grüss' type integral inequalities and applications for elementary mappings are given.

Mathematics subject classification (1991): 26D15, 26D20.

Key words and phrases: Taylor's expansion, Grüss' inequality.

\section{REFERENCES}

[1] D. S. Mitrinović, J. E. PeČArić And A. M. FinK, Classical and New Inequalities in Analysis, Kluwer Academic Publishers, Dordrecht, 1993.

[2] J. E. PEČARIĆ, S. S. DRAGOMIR AND J. SÁNDOR, On some Grüss type inequalities for isotonic functionals, Rad Hrvatske Akad. Znan. Umj. Mat., 11, (1994), 41-47. 